\title{
ЗОЛОТО-ТЕЛЛУР-ВИСМУТОВАЯ МИНЕРАЛИЗАЦИЯ В РАЗЛИЧНЫХ ТИПАХ БЛАГОРОДНОМЕТАЛЛЬНОГО ОРУ ДЕНЕНИЯ ЖЕЛЕЗИСТЫХ КВАРЦИТОВ И МЕЖРУДНЫХ СЛАНЦЕВ КУРСКОЙ СЕРИИ КМА
}

\author{
О. Г. Резникова, В. С. Кузнецов \\ Воронежский государственный университет \\ Поступила в редакцию 16 мая 2018 г.
}

\begin{abstract}
Аннотация: при исследовании технологических проб из разных генетических типов благороднометалльного оруденения в железистых кваричитах и межрудных сланцах Лебединского и Стойленского месторождений был установлен широкий спектр благороднометалльных минеральных форм, представленных самородным золотом и ассоциирующиии с ним сульфидами, висмутидами, теллуридами и другими соединениями. В сланцах обнаружено самородное золото с серебряной лигатурой, которое разделяется на 2 группь (генераџии): с пониженной (800-820\%о) и повышенной (более 850 \%о) пробностью. В кварциттах выделено золото 2-х генераций (медистое и высокопробное золото с серебряной лигатурой). Значительные концентрачии Аи сосредоточены также в сульфидах (пирите).
\end{abstract}

Ключевые слова: железистые кварииты, межрудные сланцы, благородные металль, формы нахождения, самородные металль, сульфиды.

\section{GOLD-TELLURIUM-BISMUTH MINERALIZATION OF VARIOUS TYPES PRECIOUS MINERALIZATION IN FERRUTEROUS QUARTZITES AND INTERORE SHALE OF THE KURSK SERIES KMA}

\begin{abstract}
: by the research of technological probe from different genetic types of precious mineralization in BIF and shales of the Lebedinsky and Stoylensky iron deposits were established the different mineral forms of the native gold, sulfides, bismuth, tellurium and others In slates native gold with a silver ligature which is divided into 2 groups (generation) is revealed: with lowered (800-820\%o) and raised (more than $850 \%$ ) fineness of gold. In quartzites gold of 2 generation is emitted (medisty and high-standard gold with a silver ligature). Considerable concentration of Au are in sulfides (pyrite).

Key words: ferriterous quartzites, shales, precious mineralization, sulfides.
\end{abstract}

\section{Введение}

В настоящее время, в свете поиска альтернативных или новых нетрадиционных источников благородных металлов, особое значение принимают докембрийские железистые кварциты $[1,2]$. В мегаблоке КМА докембрийского фундамента Воронежского кристаллического массива (ВКМ) находятся около 60 железорудных месторождений, в том числе ряд крупныхе и супергигантскихе, которые отрабатываются тремя ГОК-ами, обеспечивающими около 53 \% добываемого в стране железорудного сырья [3].

С железистыми кварцитами практически всех типов связаны проявления эндогенной золото-сульфидной и золото-сульфидно-кварцевой формаций, способные создавать средние по масштабам собственнозолоторудные месторождения с содержанием до 5-10 г/т и запасами от 1 до 10 и более тонн золота (Михайловское, Лебединское, Стойленское, Панковское и другие проявления) $[1,4]$. Золотоносные участки были установлены на Стойло-Лебединском рудном поле, где оруденение выявлено в зонах брекчирования, трещиноватости железистых кварцитов и межрудных сланцев, пронизанных жилами и прожилками кварца. Содержание золота в процессе переработки кварцитов и межрудных сланцев может дать достаточно высокие содержания и уже в пляжных песках отвалов (хвостохранилищ) образовать крупные месторождения [5].

Общие прогнозные ресурсы золота в железистых кварцитах и межрудных сланцах КМА, а так же металлоносных подстилающих их кварцитах стойленской свиты оцениваются геологами ОАО «Белгородгеология» $[5,6]$ не менее 2000 т. 


\section{Объекты исследования}

При написании данной статьи мы в качестве объекта исследования благороднометалльной и сопутствующей ей минерализации выбрали железистые кварциты и межрудные сланцы Лебединского и Стойленского месторождений. Эти месторождения являются крупнейшими на КМА, входят в состав Старооскольского рудного узла, расположенного в восточной части мегаблока КМА Воронежского кристалли- ческого массива (ВКМ), на южном замыкании ТимЯстребовской рифтогенной структуры [3] (рис. 1).

Месторождения сложены образованиями курской серии нижнего протерозоя. Коробковская свита курской серии сложена на 60 \% железистыми кварцитами (слаборудными, силикатно-магнетитовыми, магнетитовыми и гематит-магнетитовыми), которые формируют две железорудные подсвиты, разделенные нижней сланцевой подсвитой.

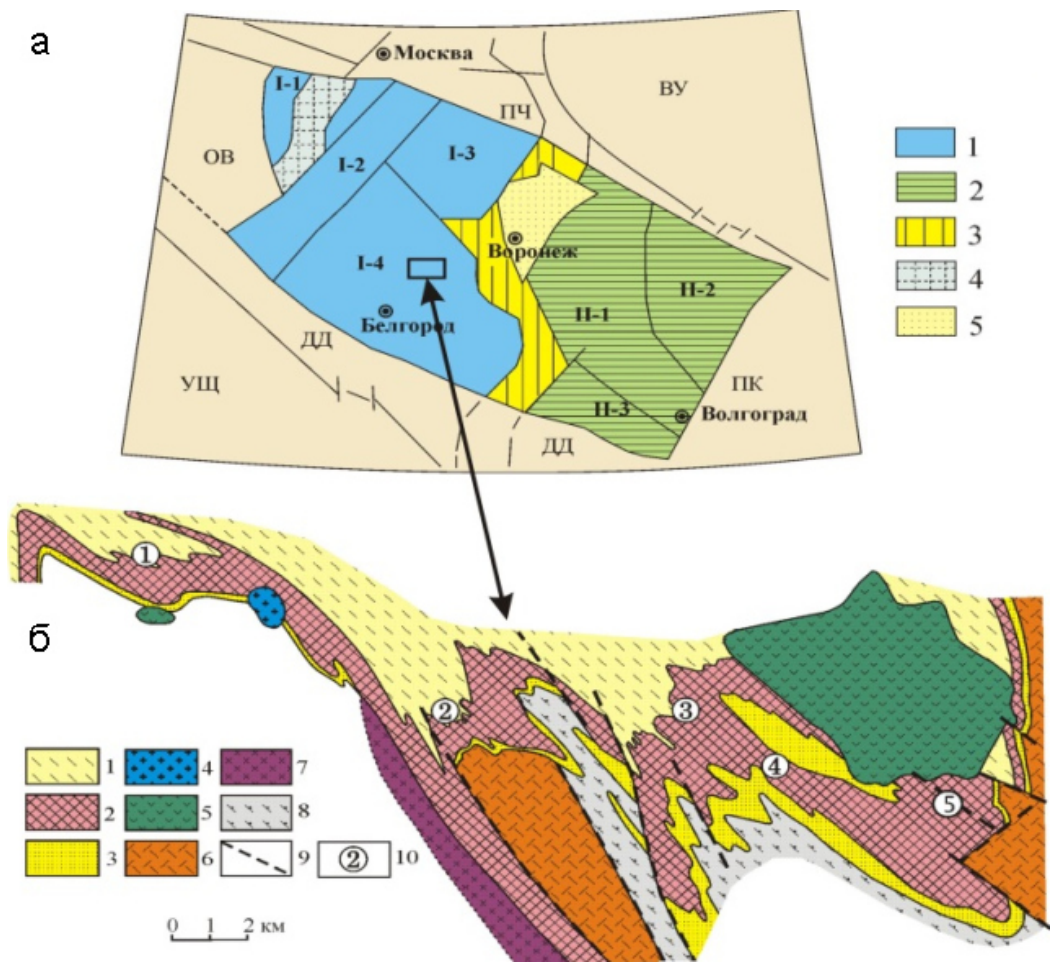

Puc. 1. Схема структурно-формационного районирования ВКМ (a; [7]): $B У-$ Волго-Уральский сегмент, ПЧ - Пачелмский авлакоген, ПК - Прикаспийская впадина, ДД - Днепрово-Донецкий авлакоген, УЩ - Украинский щит, $O B$ - Оршанская впадина. 1- мегаблок КМА (макроблоки: $I-1$ - Красногорско-Рославльский, I-2 - Брянский, I-3 - Ливенско-Ефремовский, I-4 Курско-Белгородский), 2- Хоперский мегаблок (макроблоки: II-1 - Калач-Эртильский, II-2 - Камышинский, II-3 - Варваринский), 3 - Лосевская шовная зона, 4 - ВолынскоДвинский вулкано-плутонический пояс, 5 Ольховско-Шукавская грабенсинклинальная структура. Схематическая геологическая карта Старооскольского железорудного узла (б; [3]): нижний протерозой, - курская серия: 1-2 - коробковская свита: 1 - верхняя сланцевая подсвита $\left(\mathrm{PR}^{1}{ }_{1} \mathrm{kr}_{4}\right), 2$ - верхняя и нижняя железорудные подсвиты с внутрирудной (нижней) сланцевой подсвитой $\left(\mathrm{PR}^{1}{ }_{1}\right.$ $\left.\mathrm{kr}_{3-1}\right) ; 3$ - стойленская свита $\left(\mathrm{PR}_{1}{ }_{1} \mathrm{st}\right)$ - кварцитопесчаники, кварц-слюдяные сланцы; 4 - микроклиновые граниты атаманского комплекса $\left(\mathrm{AR}_{2} \mathrm{a}\right) ; 5$ - габбродиориты, кварцевые диориты стойло-николаевского комплекса $\left(\gamma \delta \mathrm{PR}_{1}^{1} \mathrm{sn}\right) ; 6$ - нерасчлененный гранитогнейсовый комплекс

$\left(m \gamma\left(\mathrm{AR}-\mathrm{PR}^{1}{ }_{1}\right)\right.$ - гранитогнейсы, мигматиты, гнейсы, прослои и линзы амфиболитов; верхний архей - 7- плагиограниты салтыковского комплекса $\left(\gamma_{\mathrm{AR}}{ }_{2} \mathrm{sl}\right) ; 8$ - Михайловская серия $\left(\mathrm{AR}_{2} \mathrm{mh}\right) ; 9$ - разломы; 10 - месторождения: 1 - Панковское, 2 - Коробковское, 3 - Лебединское, 4 - Стойло-Лебединское, 5 - Стойленское.

Типизация благороднометалльного оруденения в железистых кварцитах и межрудных сланцах Лебединского и Стойленского месторождений КМА

Ранее [7, 8], учитывая обобщенные данные по разным месторождениям КМА (Михайловское, Лебединское и Стойленское), были выделены шесть генетических типов золото-платинометалльного оруденения в железистых кварцитах и сланцах (осадочно-метаморфогенный, метаморфогенно-метасоматический, гидротермально-метасоматический, гипергенно-метасоматический, осадочный, техногенный (россыпной)), каждый из которых характеризуется специфическими условиями локализации, морфологией и масштабами оруденения, типом минеральных ассоциаций, содержанием благородных металлов и практической значимостью. В результате предварительного опробования на благородные металлы было установлено, что наиболее перспективными в рассматриваемых объектах, учитывая масштабность проявлений, являются железистые кварциты и межрудные сланцы с признаками метаморфогенно-метасоматического и гидротермально-метасоматического типов оруденения $[9,10,11]$.

\section{Методы исследования и аналитические данные}

К ранее отобранным и изученным технологическим пробам железистых кварцитов из указанных выше типов благороднометалльного оруденения были добавлены материалы по оруденению метаморфогенно-метасоматического типа в сланцах и гидротермально-метасоматического типа в кварцитах и сланцах в пределах карьеров Лебединского и Стойленского месторождений КМА, с целью выявления собственных минеральных форм благородных металлов и сопутствующих им минералов. Для выявления минеральных форм нахождения благородных металлов были отобраны малые технологические пробы, обработанные по известной методике [13], включающей 
измельчение, гравитационную и магнитную сепарацию. Из полученного гравитационного концентрата были изготовлены препараты для микрорентгеноспектральных исследований.

1. Гидротермально-метасоматический тип оруденения:

- сульфидизированная зональная жила в магнетитовых кварцитах Лебединского месторождения (556);

- окварцованный сульфидизированный амфиболсодержащий метасоматит (528 Б) верхней железорудной подсвиты Лебединского месторождения [9];

- сульфидизированный амфиболсодержащий межрудный сланец Стойленского месторождения (СТ150) [15].

2. Метаморфогенно-метасоматический тип ору денения:

- сульфидизированный углеродсодержащий сланец нижней сланцевой подсвиты курской серии Лебединского месторождения (Л-13);

- сульфидизированные сланцы из зоны контакта железорудной и сланцевой подсвит Стойленского месторождения (СТ-18, СТ-8) [15];

- сульфидизированные слаборудные кварциты из нижней (проба А-18/2 Лебединского месторождения) и верхней (проба СТ-105 Стойленского месторождения) железорудных подсвит [9];

- сульфидизированные силикатно-магнетитовые кварциты верхней (528 А) и нижней (520) железорудных подсвит Лебединского месторождения [9];

- сульфидизированные гематит-магнетитовые кварциты из нижней железорудной подсвиты Лебединского месторождения (18/4).

\section{Обсуждение результатов}

Характеристика вещественного состава благороднометалльного оруденения различных типов

Как показали проведенные исследования, среди благородных металлов, являющихся важнейшим компонентом железистых кварцитов, количественно преобладающее золото находится преимущественно в самородном состоянии, а также в виде сплавов.

Гидротермально-метасоматический тип оруденения

Получены новые данные по благородным и сопутствующим им минералам из технологической пробы 556. Проба представлена зональной сульфидизированной жилой в магнетитовых кварцитах Лебединского месторождения. Наблюдаются: а) зона сульфидная с гидроокислами железа и скоплениями лучистых агрегатов гетита в порах и гипергенных минералах в ассоциации с мелкокристаллическим кварцем; 2) зона брекчиевой сульфидной минерализации. При изучении этой пробы обнаружено множество зерен самородного золота преимущественно с $\mathrm{Ag}$ лигатурой (табл. 1).

Таблица 1

Химический состав самородного золота из пробы 556

\begin{tabular}{|c|c|c|c|c|c|c|}
\hline \multirow{2}{*}{ № п/п } & \multirow{2}{*}{ Минерал } & \multicolumn{5}{|c|}{ Содержание, мас.\% } \\
\hline & & $\mathrm{Au}$ & $\mathrm{Ag}$ & $\mathrm{Cu}$ & $\mathrm{Fe}$ & Сумма \\
\hline 1 & Самородное золото & 79,65 & 19,1 & & & 98,75 \\
\hline 2 & Самородное золото & 81,22 & 18,78 & & & 100 \\
\hline 3 & Самородное золото & 79,51 & 19,45 & & 0,8 & 99,76 \\
\hline 4 & Самородное золото & 82,34 & 17,6 & & & 99,94 \\
\hline 5 & Самородное золото & 79,67 & 20,3 & & & 99,97 \\
\hline 6 & Самородное золото & 80,08 & 19,9 & & & 99,98 \\
\hline 7 & Самородное золото & 78,2 & 21,58 & & & 99,78 \\
\hline 8 & Самородное золото & 75,56 & 24,12 & 0,34 & & 100,02 \\
\hline 9 & Самородное золото & 78,29 & 19,66 & 0,78 & 0,85 & 99,58 \\
\hline 10 & Самородное золото & 75,32 & 24,11 & & & 99,43 \\
\hline 11 & Золото в пирите & 69,55 & 30,33 & & & 99,88 \\
\hline 12 & Золото в пирите & 71,39 & 28 & & & 99,39 \\
\hline 13 & Самородное золото & 79,35 & 20,65 & & & 100 \\
\hline 14 & Самородное золото & 80,2 & 19,7 & & & 99,9 \\
\hline
\end{tabular}

Пробность золотин от $696 \%$ до $823 \%$. Золото находится в ассоциации с теллуридами висмута (хедлиит, тетрадимит, жозеит В) и висмутовыми минералами (висмутин, самородный висмут) (рис. 2, табл.2).

Золото встречается так же в пирите в виде включений и в ассоциации с амфиболами.

Проанализирован окварцованный сульфидизированный амфиболсодержащий метасоматит (528 Б) верхней железорудной подсвиты Лебединского месторождения.

Самородное золото встречается в виде изометрических, реже - уплощенных и вытянутых зерен. Кристаллы самородного золота сложной комбинационной формы кубооктаэдрического габитуса.

Анализ встреченных минеральных срастаний самородного золота показывает, что по всей вероятности 

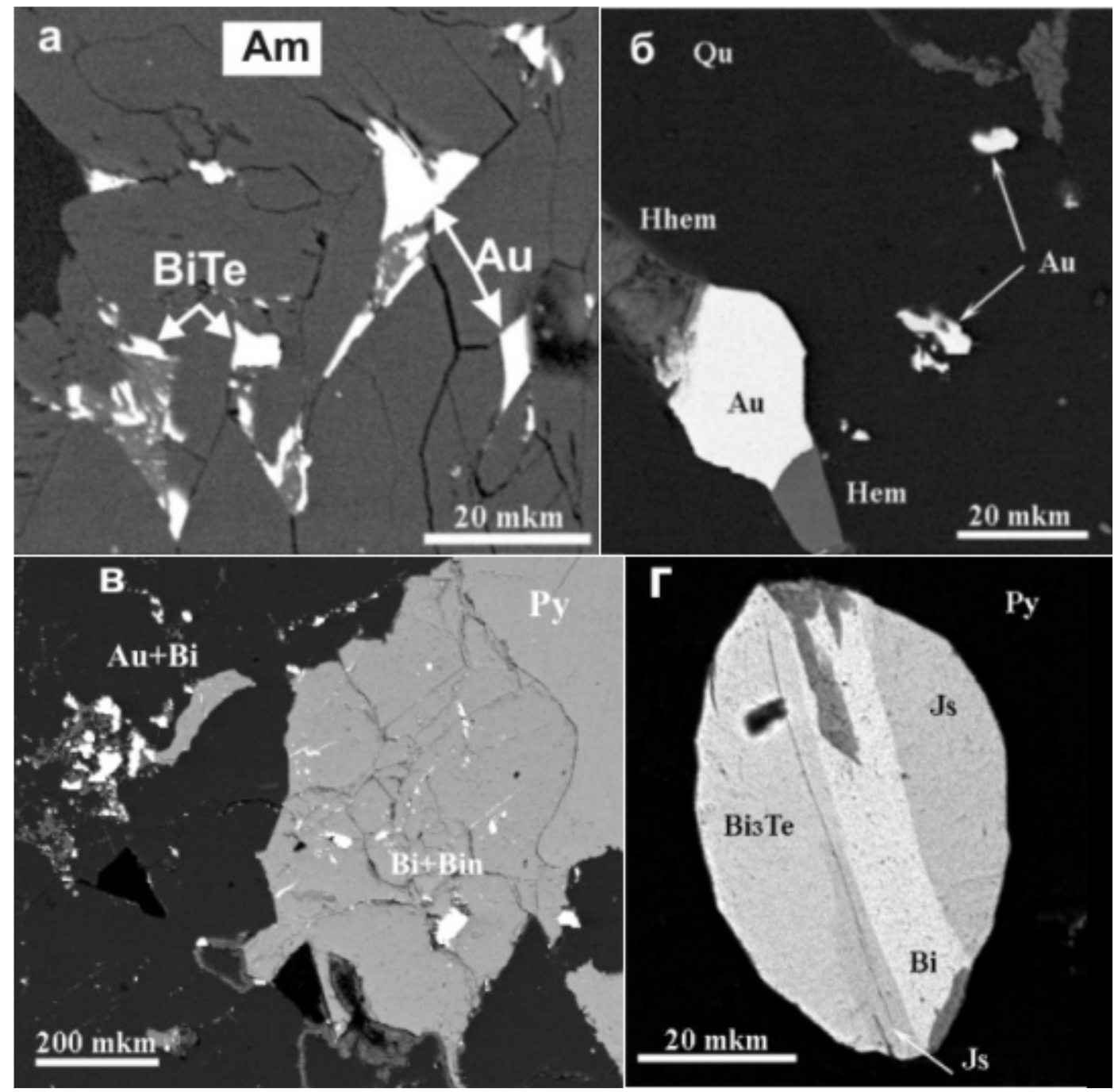

Puc. 2. Формы нахождения самородного золота и их срастания с сопутствующими минералами: $a$ - включения самородного золота и хедлиита в амфиболе. Серое в ассоциации с хедлиитом - монтанит; $\sigma$ - самородное золото в ассоциации с гематитом, гидрогематитом в кварце; 8 - контакт сульфидного прожилка (пиритового) с кварцитом. В кварце - самородный висмут с мелкими выделениями самородного золота. В пирите - срастания самородного висмута и висмутина с мелкими включениями теллуридов висмута; г - каплеобразное сложное включение в пирите висмут-хедлиит-жозеитового состава.

Таблица 2

Химический состав минералов висмута и теллур из золоторудной ассоииаџии пробы 556

\begin{tabular}{|c|c|c|c|c|c|c|}
\hline \multirow{2}{*}{$№$ п/п } & \multirow{2}{*}{ Минерал } & \multicolumn{5}{|c|}{ Содержание, мас.\% } \\
\cline { 3 - 7 } & & $\mathrm{Bi}$ & $\mathrm{Pb}$ & $\mathrm{S}$ & $\mathrm{Te}$ & Сумма \\
\hline 1 & Висмутин & 79,67 & 1,5 & 18,5 & & 99,67 \\
\hline 2 & Хедлиит & 78,79 & & & 21,2 & 99,99 \\
\hline 3 & Хедлиит-цумоит & 70,43 & & & 29,36 & 99,79 \\
\hline 4 & Хедлиит-цумоит & 67,94 & 2,33 & & 29,76 & 100,03 \\
\hline 5 & Хедлиит-цумоит & 75,35 & 1,2 & & 23,6 & 100,15 \\
\hline 6 & Хедлиит-цумоит & 70,3 & & & 29,8 & 100,1 \\
\hline 7 & Тетрадимит & 60,2 & & 4,5 & 35,5 & 100,2 \\
\hline 8 & Тетрадимит & 59,6 & & 4,6 & 35,7 & 99,9 \\
\hline 9 & Хедлиит & 83,34 & 0,7 & & 15,99 & 100,03 \\
\hline 10 & Жозеит В & 74,7 & 2,3 & 2,9 & 19,43 & 99,33 \\
\hline 11 & Самородный висмут & 99,2 & 1,2 & & & 100,4 \\
\hline
\end{tabular}

в пробе присутствует золото одной ассоциации. Эта ассоциация характеризуется отсутствием теллуридов золота и серебра, однако, здесь наблюдаются теллуриды и сульфотеллуриды висмута, что отличает эту пробу по ряду геохимических признаков $[9,12]$.

Самородное золото (724-762 \% пробности) находится обычно в срастании с халькопиритом. Обнаружено одно зерно золота (пробность $786 \%$ с хедлиита $\left(\mathrm{Bi}_{6,95} \mathrm{Te}_{3}\right)$.

Среди сульфотеллуридов висмута установлены жозеит $\mathrm{A}\left(\mathrm{Bi}_{3,7} \mathrm{TeS}_{2}\right)$ и тетрадимит $\left(\mathrm{Bi}_{2} \mathrm{Te}_{2} \mathrm{~S}\right)$. Взаимоотношений этих минералов с золотом обнаружить не удалось.

Пробность самородного золота в пробе характеризуется широкими вариациями: от $563 \%$ до $862 \%$. Однако в этой пробе 
основная часть золота принадлежит узкому классу пробности - от $700 \%$ до $800 \%$. Средняя пробность в пробе - $740 \%$ при 33 замерах [9].

В препарате пробы СТ-150, отобранной из интенсивно сульфидизированных амфиболсодержащих сланцев, обнаружены многочисленные изометрические зерна и кристаллы (кубической и более сложной формы) самородного золота (проанализировано 41 зерно). Средние размеры золотин составляют 25-40 мкм. Средняя пробность золота $-880 \%$, лигатура серебро, в четырех пробах (около $10 \%$ ) - медь. Здесь отмечается более широкий разброс пробности, однако преобладает более высокопробная генерация. Золото находится как в свободной форме, так и в срастании с пиритом, самородным висмутом, хедлеитом и цумоитом. Из минералов висмуто-теллуридной ассоциации в пробе СТ-150 присутствуют также пильзенит и тетрадимит [13].

\section{Метаморфогенно-метасоматический тип оруденения}

Благороднометалльное оруденение этого типа широко проявлено как в различных геолого-промышленных типах кварцитов (слаборудных, силикатномагнетитовых, магнетитовых, гематит-магнетитовых), так и в межрудных сланцах.

\section{Межрудные сланщь}

В препарате пробы сланцев СТ-18, отобранной в зоне контакта железорудной и сланцевой подсвит в северо-восточной части Стойленского карьера, обнаружено большое количество (сотни зерен) самородного золота. Самородное золото (с серебряной лигатурой) разделяется на две группы $[10,13,14]$. Одна из них, более редкая, имеет пониженную пробность (800-820 \%о) (. 3a), другая - повышенную (более 850 $\%$ ), иногда помимо серебра содержит незначительную примесь меди (.3б). Высокопробная генерация золота имеет более широкое распространение, парагенетически она связана с сульфидной полиметаллической (арсенопирит-галенит-халькопирит-пиритовой минерализацией). Отмечаются включения самородного золота в пирите, сростки его с сульфидами (пиритом, халькопиритом).

Вторая (низкопробная) генерация золота распространена более ограниченно. Ее отличительной чертой является характерный парагенезис с теллуридами золота, серебра и висмута. Более низкопробное золото образуется позже высокопробного, поскольку в их срастаниях низкопробное золото приурочено к периферическим зонам и ассоциирует с низкотемпературными минералами, такими как мальдонит (рис. 3в). В ассоциации с минералами благородных металлов в
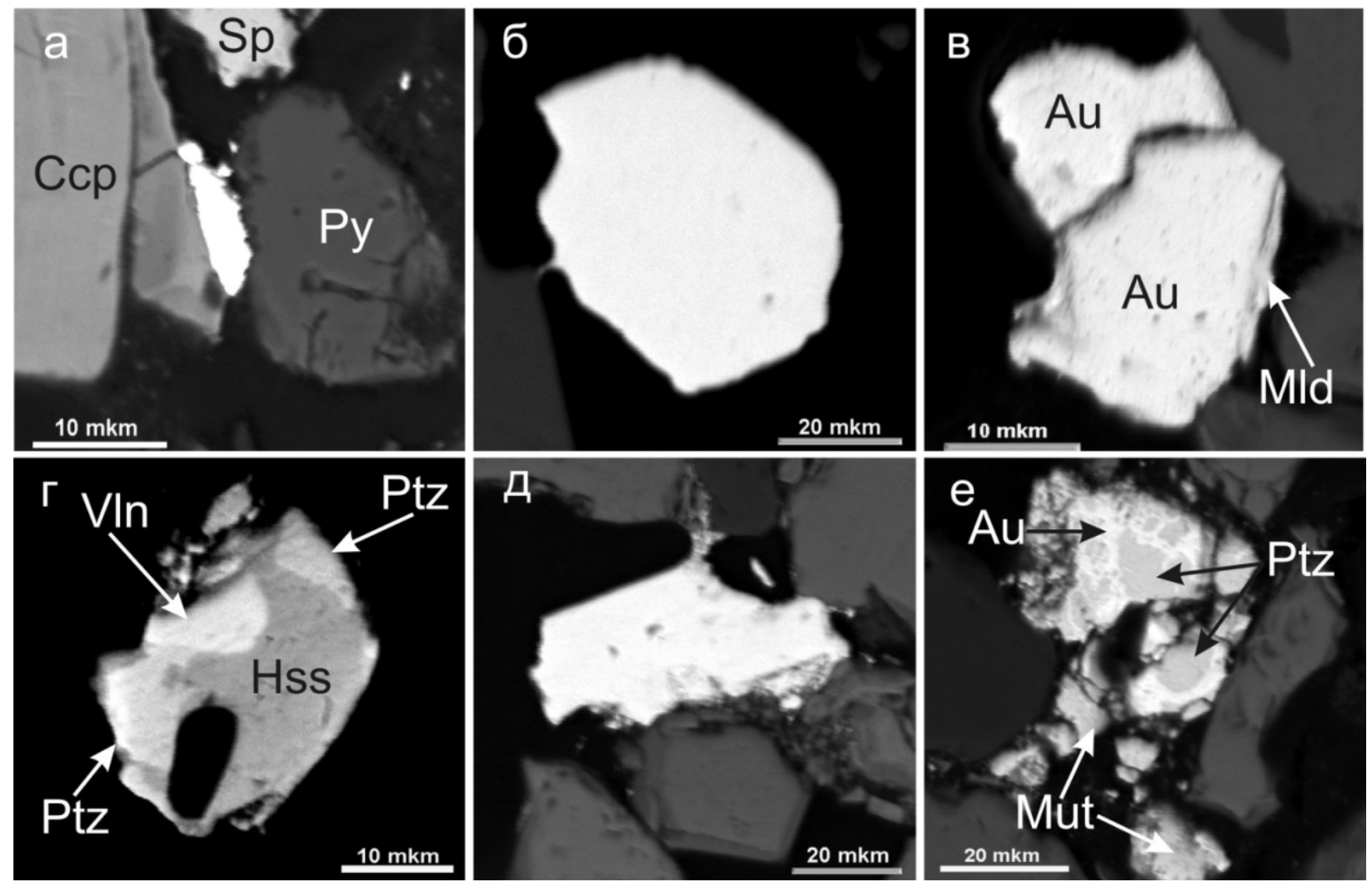

Puc. 3. Формы выделения самородного золота и сопутствующих минералов из тяжелой фракции концентрата минералогических проб амфиболсодержащих сланцев (проба СТ-18): $a$ - пластинчатое золото в срастании с халькопиритом (Сср) на границе с пиритом (Ру), вверху светло-серое зерно сфалерита (Sp); $\sigma$ - зерно высокопробного самородного золота; 8 - срастание самородного золота $(\mathrm{Au})$ различного состава (сверху золотина с пробностью $955 \%$,а внизу - 819\%o), на периферии более низкопробного зерна оторочка мальдонита (Mld); 2 - сросток теллуридов благородных металлов петцита (Ptz), гессита (Hss) и волынскита (Vln); $\partial$ - кристалл сильванита (в центре); $e$ - замещение петцита самородным золотом и мутманнитом (Mut). 
пробе наблюдаются барит и монацит [13].

В процессе микроскопического исследования пробы СТ-18 помимо сульфидных минералов (пирит, халькопирит, галенит, сфалерит) были установлены [10]: висмут самородный, теллуриды висмута, алтаит $\left(\mathrm{Pb}_{1,004} \mathrm{Te}_{0,943} \mathrm{~S}_{0,057}\right)$, цумоит $\left(\mathrm{Bi}_{0,97} \mathrm{Te}\right), \quad$ петцит $\left(\mathrm{Ag}_{2,99} \mathrm{Au}_{1,02} \mathrm{Te}_{2}\right)$ и сильванит $\left(\mathrm{Au}_{1,27} \mathrm{Ag}_{0,78} \mathrm{Te}_{4}\right)$. Видовой состав благороднометалльной минерализации удалось расширить при исследовании тяжелых фракций гравитационного концентрата проб. Здесь, кроме перечисленных выше минералов, были обнаружены: волынскит $\left(\mathrm{Ag}_{1,03} \mathrm{Bi}_{1,01} \mathrm{Te}_{2}\right)$, мутманнит $\left(\mathrm{Au}_{0,97} \mathrm{Ag}_{1,02} \mathrm{Te}_{2}\right)$, мальдонит $\left(\mathrm{Au}_{1,98} \mathrm{Ag}_{0.14} \mathrm{Bi}\right)$, гессит $\left(\mathrm{Ag}_{2} \mathrm{Te}\right)$ (рис.3 г-е).

Получены новые данные по минеральным ассоциациям в тяжелой фракции из пробы межрудных сланцев Лебединского месторождения Л-13. Среди минералов благороднометалльной ассоциации наиболее часто встречаются сульфиды, теллуриды, висмутиды, а также самородные фазы (табл. 3). Сульфиды цветных металлов представлены галенитом, сфалеритом, борнитом, халькопиритом, минералами группы халькозина и др.

Таблица 3

Химический состав минералов золота и серебра, ассочиирующих с самородным золотом в межрудных сланиах Лебединского месторождения (масс \%)

\begin{tabular}{|c|c|c|c|c|}
\hline Минерал & Акантит & Цумоит & Петцит & Гёссит \\
\hline $\mathrm{Au}$ & & 1,54 & 25,24 & 1,71 \\
\hline $\mathrm{Ag}$ & 86,73 & & 42,08 & 61,09 \\
\hline $\mathrm{S}$ & 13,07 & & & \\
\hline $\mathrm{Te}$ & & 38,42 & 33,11 & 34,9 \\
\hline $\mathrm{Bi}$ & & 59,95 & & 2,32 \\
\hline $\mathrm{Cумма}$ & 99,80 & 99,91 & 100,43 & 100,02 \\
\hline \multicolumn{5}{|c|}{ Формульные коэффициенты } \\
\hline $\mathrm{Au}$ & 0,03 & 0,99 & 0,03 \\
\hline $\mathrm{Ag}$ & 1,99 & 3,01 & 1,98 \\
\hline $\mathrm{S}$ & 1,01 & 1,01 & 2,00 & 0,95 \\
\hline $\mathrm{Te}$ & $\mathrm{B}$ & 0,96 & & 0,04 \\
\hline $\mathrm{Bi}$ &
\end{tabular}

Самородное золото достаточно высокопробное, для него характерны тесные срастания с золотосеребряными сплавами, петцитом, гесситом и цумоитом, сульфидами серебра, халькопиритом и магнетитом. Средняя пробность минерала составила 943 \%о (вариация 825-998 \%о по 19 определениям), содержание примеси серебра 4,1 \%; более $40 \%$ золотин содержат заметную примесь меди $(0,3-8,8 \%)$ (рис. 4).

\section{Слаборудные кваричить}

Представлены двумя пробами из нижней и верхней железорудных подсвит Лебединского и Стойленского месторождений. Благородные металлы представлены высокопробным самородным золотом с примесью меди и серебра.

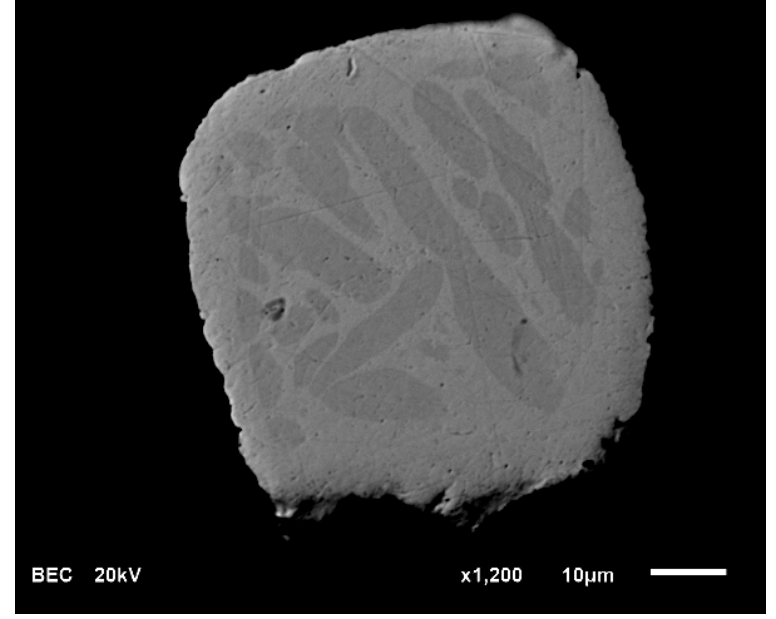

Puc. 4. Сечение кристалла самородного золота с включениями медистого золота. Темные балки - пробность $905 \%$, $\mathrm{Ag}-0,65 \% ; \mathrm{Cu}-8,8 \%$. Светлая матрица - пробность $911 \%$, $\mathrm{Ag}-6,1 \% ; \mathrm{Cu}-2,8 \%$. Изображение BSE.

Состав самородного золота в пробе сульфидизированных слаборудных магнетитовых кварцитов из нижней подсвиты Лебединского месторождения характеризуется 939 пробностью, а среди примесей характерна медь (0,4-2,3 мас.\%). В этой пробе встречено трехфазное зерно самородного золота в срастании с серебряным сплавом промежуточного состава (50:50 в ат.\%) и петцитом $\left(\mathrm{Ag}_{3} \mathrm{AuTe}_{2}\right)$ [9].

Такая же ассоциация высокопробного золота (920$990 \%$, редко снижаясь до 840-760\% наиболее широко представлена в пробе из слаборудных кварцитов верхней железорудной подсвиты Стойленского месторождения (СТ-105) [9, 10, 13, 14]. Вторая генерация представлена медистым золотом с содержанием меди от долей процента до $\mathrm{Au}_{2} \mathrm{Cu}$ и $\mathrm{AuCu}$ (тетрааурикуприд), по всей вероятности это наиболее ранняя мало распространенная его генерация. Для самородного золота из пробы СТ-105 (Стойленского месторождения) характерны изометрические формы и ассоциации с минералами висмута $[9,10,13$, 14]. В качестве ассоциации с самородным золотом обнаружены сотни зерен минералов висмута (по мере снижения распространенности): самородный висмут, висмутин, тетрадимит и значительно более редко наблюдаются жозеит (жозеит А) и лиллианит, а так же шеелит, барит и уранинит, содержащий значительную примесь радиогенного свинца [13].

Наблюдается также генетическая связь благородных металлов с сульфидами. В одном из кубических кристаллов пирита отмечено мельчайшее включение высокопробного самородного золота, в другом - тетрадимита [13].

\section{Силикатно-магнетитовые кваричиты}

Представлены двумя пробами из нижней (520) и верхней (528А) железорудных подсвит Лебединского месторождения. В этих породах пробность самородного золота несколько ниже, чем в слаборудных кварцитах $(\sim 781 \%$ из нижней железорудной подсвиты. 
В обеих пробах присутствует в небольшом количестве серебро. Морфология зерен самородного золота такая же, как и в пробах слаборудных кварцитов, чаще всего изометричная, иногда почти округлая. Пластинчатые формы отмечаются только у мелких золотин. Иногда встречаются кристаллы самородного золота, которые, судя по случайным сечениям, представлены октаэдрами.

Помимо свободных золотин в пробе встречены сростки с другими минералами: с халькопиритом, галенитом, петцитом, гесситом, маккинстриитом, а так же креннеритом, пиритом и борнитом. Причем наибольшая пробность золотин наблюдается в срастании с галенитом и борнитом $(875 \%$, тогда как с халькопиритом, креннеритом и пиритом пробность резко снижается $(654 \%$ \% $)$ [9].

\section{Гематит-магнетитовые кваричиты}

В сульфидизированных гематит-магнетитовых кварцитах (проба А-18/4, Лебединское месторождение) пробность золота относительно пониженная (893 $\%$ ). В этой пробе в отдельных зернах самородного золота наблюдается повышенная концентрация меди до 11,6 мас.\% [9].

\section{Интерпретация полученных результатов}

Образования железисто-кремнисто-сланцевой формации в пределах мегаблока КМА в настоящее время имеют наибольшее распространение в пределах протерозойских рифтогенных грабенсинклинальных структур, в которых сохранились от размыва наибольшие мощности отложений курской и оскольской серий. Вышеназванные структуры характеризуются развитием в оскольское время разномасштабной тектоно-магматической активности, сопровождавшейся широким развитием флюидногидротермальной деятельности и многоактным проявлением вулкано-интрузивного магматизма. С постмагматическими процессами, протекавшими в результате внедрения в метаморфизованные осадочные толщи позднепалеопротерозойских интрузивных тел, связано золотоносное оруденение. Вышеназванные процессы в породах курской серии в пределах Тим-Ястребовской структуры привели к образованию зон гидротермальных изменений пород, развитию процессов метасоматоза, сопровождающихся наложенной благороднометалльной минерализацией. Оруденение имеет отчетливую наложенную природу, несет признаки связи со структурно-тектоническими факторами и влияния, в различных случаях, как флюидно-магматических систем гранитоидов (от диоритов и гранодиоритов до плагиогранитов и субщелочных гранитов) и их дайковых фаций (стойло-николаевский и малиновский комплексы) [7].

\section{Заключение}

Изучение вещественного состава золоторудной минерализации различных типов благороднометалль- ного оруденения в железистых кварцитах и межрудных сланцах курской серии показало, что наиболее перспективными и широко развитыми в изучаемых породах являются метаморфогенно-метасоматический и гидротермально-метасоматический типы, характеризующиеся схожестью состава благороднометалльной минерализации. В них наиболее широко представлена минеральная ассоциация, в которую входят $\mathrm{Au}-\mathrm{Ag}$ минералы халькофильной специализации (самородное золото, теллуриды, висмутиды и селениды золота и серебра (иногда с палладием), $\mathrm{Au}-$ содержащие сульфиды), приуроченная к эпигенетическому оруденению, связанному, по мнению ряда исследователей [2, 7], с магматизмом основного, среднего и кислого состава, наиболее полно проявившегося на этапе протерозойского рифтогенеза и последующей коллизии мегаблоков Воронежского кристаллического массива.

В выводах нужно ограничиться только минералогией новой пробы 556 и убрать отвлеченные и бездоказательные рассуждения о генезисе золоторудной минерализации.

\section{ЛИТЕРАТУРА}

1. Шелехов, А. Н. Месторождения железистых кварцитов и продукты их передела - новый перспективный источник золото-платиносодержащего сырья в XXI веке (на примере Центральной России) / А. Н. Шелехов, В. А. Лючкин, Ю. С. Ляховкин. // Платина России. Проблемы развития минерально-сырьевой базы платиновых металлов в XXI веке. Сборник научных трудов. Т 3, в 2-х кн,- Москва $3 \mathrm{AO}$ «Геоинформмарк», - 1999. - С. 289-294.

2. Двойнин, В. В. Золотоносность железистых кварцитов курской серии КМА / В. В. Двойнин, Е. И. Дунай, И. И. Воевода // Разведка и охрана недр - 1993. - № 9. - С.12-14.

3. Орлов, В. П. Железные руды КМА / В. П. Орлов // М.: Геоинформмарк. $-2001 .-616 \mathrm{c}$.

4. Чернышов, Н. М. Золото-платиноносность главнейших типов железорудных формаций мира (информационноаналитический обзор) / Н. М. Чернышов, С. П. Молотков, О. Г. Резникова // Вестн. Воронеж. гос. ун-та. Сер. : Геология. 2003 - 2. - С.137-162.

5. Дунай, Е.И. Состояние, проблемы и задачи по развитию и укреплению минерально-сырьевой базы Центрального Черноземья России (на примере Белгородской области) / Е. И. Дунай, В. И. Белых, И. Ф. Плужников // 1998. - № 6. C.131-142.

6. Кушнеренко, В. К. Золото и другие элементы в железорудных месторождениях КМА (к проблеме комплексного использования) / В. К. Кушнеренко, Ю. М. Шувалов, В. М. Мятлин // Региональная геология и металлогения. - С.-Пб.: Изд.-во ВСЕГЕИ. - 1999. - № 9. - С. 120-124.

7. Чернышов, Н. М. Платиноносные формации КурскоВоронежского региона (Центральная Россия) / Н. М. Чернышов // Воронеж: Изд-во Воронеж. гос. ун-та , 2004. - 448 с.

8. Чернышов, Н. М. Благороднометалльносодержащие парагенезисы сульфидов и их аналогов в железорудных месторождениях КМА (Центральная Россия)/ Н. М. Чернышов. // Вестн. Воронеж. гос. ун-та. Сер. : Геология. 2007. № 1. - C.101-114.

9. Чернышов, Н. М. Типы, состав и генетические особенности золото-платинометалльного оруденения в железистых кварцитах Старооскольского рудного района КМА (Цен- 
тральная Россия) / Н. М. Чернышов, О. Г. Резникова // Воронеж: Изд-во Воронеж. гос. ун-та -, 2014. - 156 с.

10. Кузнецов, В. С. Зололото-платинометалльное оруденение в межрудных сланцах Стойленского железорудного месторождения КМА (типы, состав и генетические особенности) / В. С. Кузнецов // автореф. дис. ... к. геол.-мин. наук. Воронеж: ВГУ, 2010. - 24 с.

11. Чернышов, Н. М. Типы, закономерности размещения и состав золото-платиноидного оруденения в месторождениях-гигантах КМА. Новый источник стратегически важных металлов (Центральная Россия) / Н. М. Чернышов // Материалы международной конференции, посвященной 90летию Воронежского государственного университета. Воронежпечать - 2008. - С. 216-218.

12. Чернышов, Н. М. Формы нахождения благородных металлов в разнотипных железистых кварцитах и их мета-

\section{Воронежский государственный университет}

Резникова Ольга Григорьевна, кандидат геологоминералогических наук, дочент кафедры минералогии, петрографии и геохимии

E-mail:reznikova_o@bk.ru

Тел.: 8-473-220-79-66

Кузнечов Владислав Сергеевич, кандидат геологоминералогических наук, дочент кафедры минералогии, петрографии и геохимии

E-mail: voronezhpodkl@inbox.ru

Тел.: 8-473-220-79-66 соматитах Лебединского и Стойленского месторождений (КМА) / Н. М. Чернышов, О. Г. Резникова // 2010. - № 1. C. $135-144$.

13. Золотоносность Стойленского месторождения КМА (типы и состав благороднометалльного оруденения) / Н. М. Чернышов [и др.] // Руды и металлы. - 2009. - № 6. - С. $48-55$.

14. Чернышов, Н. М. О золотоносности пород и руд Стойленского месторождения / Н. М. Чернышов, В. С. Кузнецов, О. Г. Резникова // 2009. - № 1. - С. 103-110.

15. Кузнецов, В.С. Минералы благородных металлов в стратифицированных комплексах палеопротерозоя Курской магнитной аномалии как показатели природы золотоплатинометалльного оруденения / В. С. Кузнецов, В. В. Абрамов // Записки РМО. - 2013. - № 5. - С. 53-63.

\section{Voronezh State University}

Reznikova O. G., Candidate of Geological and Mineralogical Sciences, Associate Professor of the Mineralogy, Petrography and Geochemistry Department

E-mail: reznikova_o@bk.ru

Tel.: 8-473-220-79-66

Kuznetsov V. S., Candidate of Geological and Mineralogical Sciences, Associate Professor of the Mineralogy, Petrography and Geochemistry Department

E-mail: voronezhpodkl@inbox.ru

Tel.: 8-473-220-79-66 